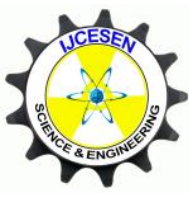

Copyright (C) IJCESEN
International Journal of Computational and

Experimental Science and $\boldsymbol{E N g i n e e r i n g}$

(IJCESEN)

Vol. 5-No.3 (2019) pp. 124-130

http://dergipark.gov.tr/ijcesen

Research Article

\title{
Optimization of Air Distribution in A Non-Ducted Concealed Type Fancoil Unit Heat Exchanger
}

\author{
Murat OZSOY ${ }^{1 *}$, Canberk YUCEL ${ }^{2}$, Onur VARLICA ${ }^{2}$, M. Serhan KILIC ${ }^{2}$, Kagan \\ KAPLAN $^{2}$
}

\author{
${ }^{1}$ Sakarya University, Engineering Faculty, Mechanical Engineering Department, Sakarya, TURKEY \\ ${ }^{2}$ DAIKIN Turkey, R\&D Department, Sakarya, TURKEY
}

* Corresponding Author : ozsoy@ sakarya.edu.tr

ORCID: 0000-0003-2400-5212

\section{$\underline{\text { Article Info: }}$}

DOI: $10.22399 /$ ijcesen.479810

Received : 07 November 2018

Accepted : 24 September 2019

\section{Keywords}

Fancoil

Air distribution

Computational fluid dynamics

\begin{abstract}
$\underline{\text { Abstract: }}$
In this study, increasing efficiency of a heat exchanger as a sub part of concealed ceiling type fan coil unit is aimed. Accordingly, by determining rotational speed of fans based on actual design; generated air distribution in dry condition on heat exchanger is investigated via computational fluid dynamics software. Significant low air distribution is detected in lower and higher sides of the heat exchanger. In order to create solution to this issue and to increase efficiency, by designed air distributor, homogenized air distribution is targeted. As a conclusion, differentiation of air velocities and air distribution is investigated based on various angles. By means of the distributor with an optimum design angle, air distribution is improved and more homogenous air distribution is achieved.
\end{abstract}

\section{Introduction}

Energy is one of the most sensitive factors that determine the boundaries of technology, industry, production and economy of today's world. Particularly in the last years, energy efficiency has become even more important on a national and global scale. Energy consumption restrictions has been tightened together with various legal requirements; research activities, development activities and investment studies aimed at raising the productivity as much as cost have gained momentum at a remarkable rate.

Considering the mentioned situations above, the same search is inevitable in the areas of heating, cooling and air conditioning. These needs, which can lead to high costs, especially by creating the most lucrative consumption of living environments, spaces and rooms, are of great financial importance to the people.

In order to meet the requirements that arise in this direction, there are many solutions such as room air conditioners, boiler systems, air handling units, hybrid systems. Among these, fancoil units are at the forefront, especially with the costs and technical features of multiple application requirements. The use of these equipment, which offer flexible solutions through different installation combinations is becoming more common day by day, considering the rise in architectural investments in parallel with population growth. For these reasons, the focal point of the work is a heat exchanger of a fan coil unit.

Heat exchanger performance is directly affected by parameters such as, inclination [1], distances between fins (fin pitch) [2], fin shape differences [3] and air distribution on heat exchanger [4].

Moreover, in the fancoil design, it is very important that the device has a compact structure. The cooling and heating capacity of the unit depends on the power consumption of fan motor, the air being easily sucked from the environment, the air being distributed homogeneously on the heat exchanger surface and blowing at a suitable speed and angle. For the device to work quietly, the fan motor and fan noise levels must be low as well as the air velocity. 
In a unit with a certain airflow, the speed of the air changes as it passes through different sections of the unit. These changes are especially important on the heat exchanger inlet surface, as the more uniform the air is distributed to the battery surface, the better battery efficiency and therefore the performance of the device. [5]

When the specified performance factors are analyzed in this research it is aimed that, unlike other studies, the air distribution on the heat exchanger is improved by homogenization, thus a more uniform air distribution is achieved in the fan coil unit.

\section{Fancoil Unit}

\subsection{Definitions and Details}

According to Eurovent's definition [6], a fancoil unit is a factory-made assembly which provides the functions of cooling and/or heating air using chilled or hot water with air flow to the room ensured by one or more electrically driven fans. The principal components are as following:

One or more heat exchangers

One or more fans with electric motors

An appropriate enclosure

Condensed water collecting facilities when cooling

Air filter

\subsection{Test Requirements}

Tests carried out by Eurovent during standard and application ratings are conducted in selected laboratories in compliance with the following standards:

Performance and airflow tests are carried out according to the standard EN 1397:2015 "Heat exchangers- Hydronic- Room fan coil units- Test procedures for establishing the performance" in fan rotations (slow fan, medium fan and high fan) selected by Eurovent.

Sound level test is carried out according to the standard EN 16583:2015 "Heat exchangers. Hydronic room fan coils units. Determination of the sound power level" in declared 3 fan rotations (slow fan, medium fan and high fan).

In order to evaluate with flow simulation, nonducted ceiling type fancoil unit is preferred due to main reasons such as being the most widely selected product type in projects, due to its compact structure, the heat exchanger air distribution values are of greater importance and the implementation regions are at low external static pressure.

\section{Analysis Study}

\subsection{Specification of Determined Unit}

A fun coil Unit (FCU) sub-parts targeted for air distribution detection and improvement are modeled with Solidworks 2015 CAD software and the assembly process of the parts is completed through the same software. In this way, the required model for Solidworks Flow Simulation, a sub-module of the software and a solution for the computational fluid dynamics, has been created. The characteristics of the elements forming the fancoil unit preferred for modeling are as follows:

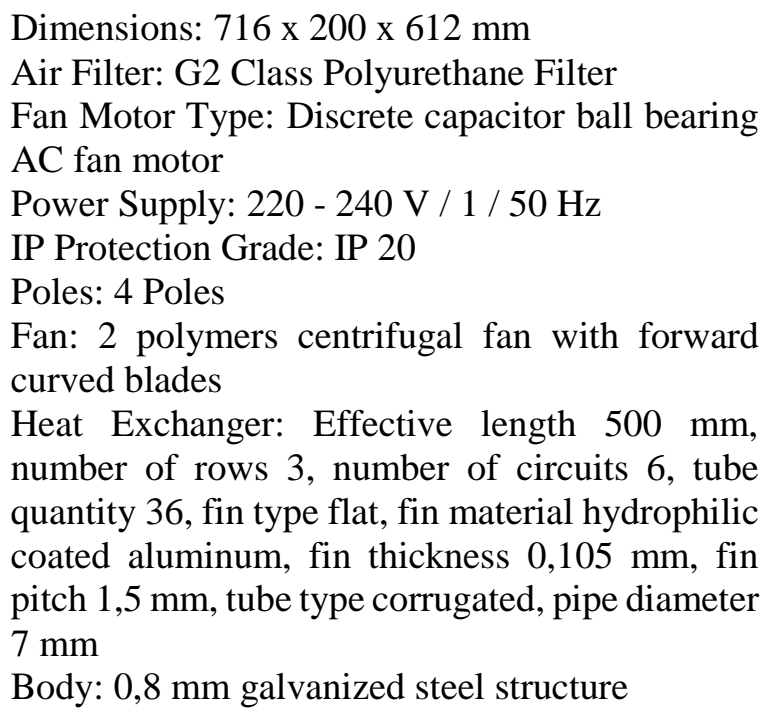

\subsection{Environmental Conditions and FCU Inputs}

Input parameters must be defined in order to be able to evaluate the Fancoil unit modeled with SolidWorks 2015 software through Flow Simulation, an integrated analysis module. In this direction, the air flow simulation in the fan coil units is performed in fan only mode, and the air flow simulation is also performed in fan only mode. In this case, the flow form formed in the heat exchanger is determined in the unit operating in the ambient conditions. Details of the environmental conditions determined for flow analysis are as follows:

Environment fluid: Air (laminar and turbulent flow, specific heat ratio $\mathrm{cp} / \mathrm{cv}=1,399$ )

Environmental Pressure: 0,1013 MPa

Environment Temperature: $20{ }^{\circ} \mathrm{C}$

Relative Humidity: \%50

Flow is considered incompressible and time independent.

For fan speed selection, which is another parameter to be specified as input, the main decision factor is the number of fan motor speeds that will be defined to operate the fancoil unit in high speed mode. For 
this reason, the optimum fan speed should be preferred through the fan efficiency curves that can be supplied by the fan motor manufacturers. In this study, the fan rotation speed determined by considering the existing AC fan motor is 950 RPM.

\subsection{Boundary Conditions and Mesh Determination}

The area to be used for the calculation in the analysis was chosen considering the dimensions of the fan coil unit and the actual ceiling space conditions. This definition is shown in Figure 1. and the dimensional details of the relevant boundary conditions are shown in Table 1.

Table 1. Determined boundary dimensions

\begin{tabular}{|l|l|}
\hline$X_{\text {min }}=-750 \mathrm{~mm}$ & $X_{\max }=750 \mathrm{~mm}$ \\
\hline$Y_{\text {min }}=-750 \mathrm{~mm}$ & $Y_{\max }=750 \mathrm{~mm}$ \\
\hline$Z_{\text {min }}=-250 \mathrm{~mm}$ & $Z_{\max }=750 \mathrm{~mm}$ \\
\hline
\end{tabular}
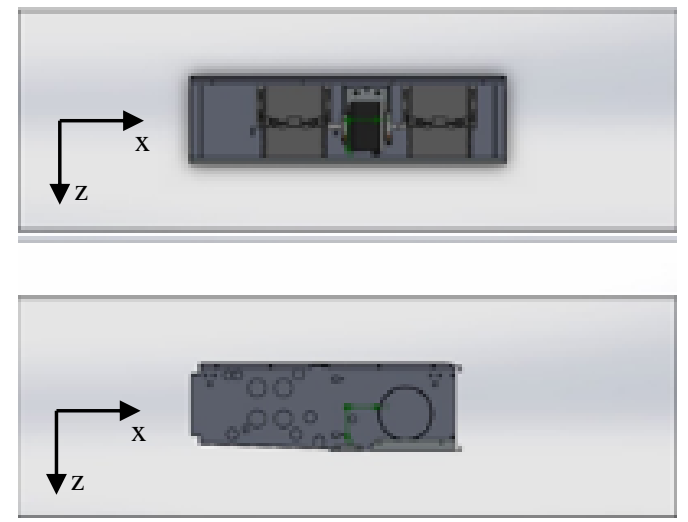

Figure 1. Determined boundary area

Before performing data analysis in addition to defining boundary conditions, one of the existing requirements is to determine the mesh specification. In order to achieve optimal computation speed and calculation accuracy within available conditions, the $6^{\text {th }}$ level mesh from $8^{\circ}$ mesh scales is selected in frame of SolidWorks Flow Simulation software. The details of the mesh in this direction are shown in Table 2 .

Table 2. Mesh details

\begin{tabular}{|c|c|}
\hline Total Cells & 53697 \\
\hline Fluid Cells & 35578 \\
\hline Solid Cells & 163 \\
\hline Partial Cells & 17956 \\
\hline Cropped Cells & 3 \\
\hline
\end{tabular}

\subsection{Determination of Existing Airflow Distribution}

In the first phase of the work, it is aimed to determine the available air distribution in the heat exchanger.
In this direction, copper pipes lined on the heat exchanger are numbered from top to bottom, as shown in Figure 2. in order to make it possible to investigate the distribution to be generated. By this way, the flow rate around the copper tubes in each row will be recorded and investigated for evaluation. Afterwards, the air distributors will be detected which will guide the air distribution to the optimum by means of the findings obtained by different wing angles.

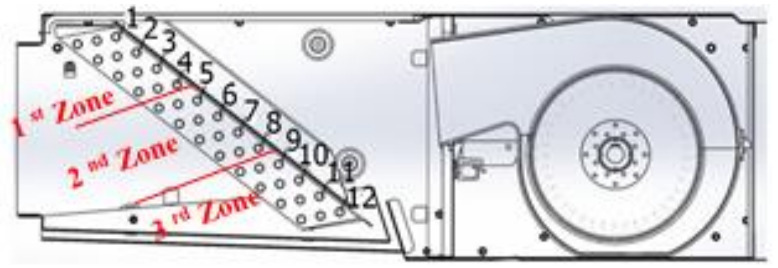

Figure 2. Copper pipe numbering of FCU

After the numbering of the pipes in which the air absorbed by the fan primarily contacted the heat exchanger, numerical analysis was carried out with the specified ambient conditions, boundary conditions and mesh structure. The flow velocities around the pipe are shown on the cross-section based on the fan center plane.

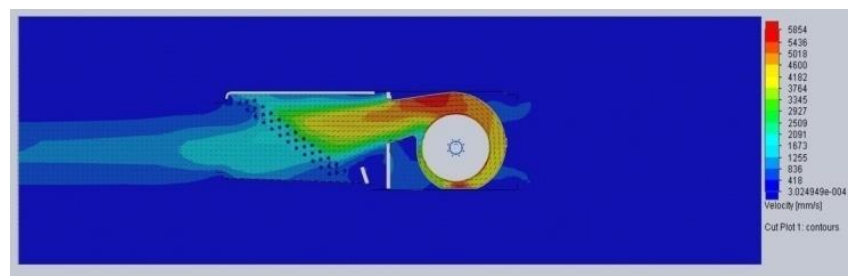

Figure 3. Airflow distribution at initial state for left fan center plane

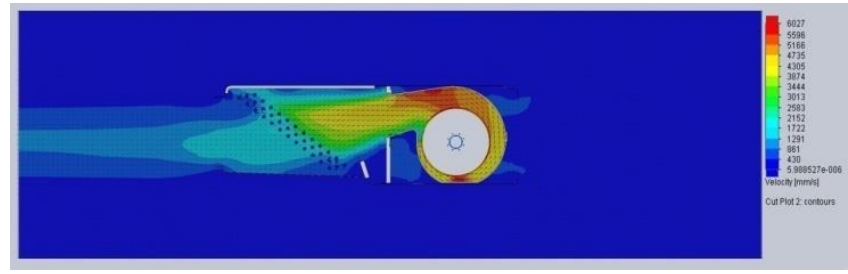

Figure 4. Airflow distribution at initial state for right fan center plane

When the Table 4.3. which is created by the airflow analysis on the existing FCU design is investigated, the inhomogeneous air distribution is numerically observed. The flow velocity around the copper tubes in the upper ( $1^{\text {st }}$ zone) and lower $\left(3^{\text {rd }}\right.$ zone) regions of the heat exchanger is very low compared to the air velocity in the central zone ( $2^{\text {nd }}$ zone $)$. It is observed

Table 3. Maximum air velocities on heat exchanger at initial state 


\begin{tabular}{|c|c|c|}
\hline $\begin{array}{c}\text { Copper } \\
\text { Pipe No }\end{array}$ & $\begin{array}{c}\text { Left Fan Air } \\
\text { Velocity (mm/s) }\end{array}$ & $\begin{array}{c}\text { Right Fan Air } \\
\text { Velocity (mm/s) }\end{array}$ \\
\hline 1 & 396.934 & 437.354 \\
\hline 2 & 504.89 & 549.828 \\
\hline 3 & 919.998 & 886.105 \\
\hline 4 & 2513.85 & 2474.688 \\
\hline 5 & 2508.369 & 2489.996 \\
\hline 6 & 2623.353 & 2661.75 \\
\hline 7 & 2642.554 & 2703.829 \\
\hline 8 & 2443.594 & 2265.297 \\
\hline 9 & 2421.774 & 2212.368 \\
\hline 10 & 631.439 & 716.374 \\
\hline 11 & 1022.991 & 1316.357 \\
\hline 12 & 493.804 & 713.529 \\
\hline
\end{tabular}

that there is a very high increase after air flow values around copper pipes 1, 2 and 3. Likewise, after copper pipe 9, a high decrease is observed. In this direction when the pipes are determined, it is aimed to improve the air velocity corresponding to copper pipes in the upper zone $(1,2,3)$ and located in the lower zone $(10,11,12)$ of the heat exchanger.

\subsection{Determination of Airflow Generated with $15^{\circ}$ Angled Distributor}

In this phase, the air distributor (with $60 \mathrm{~mm}$ length and $5 \mathrm{~mm}$ thickness) located in the position shown in Figure 5, placed between the right and left side plates in the FCU, is positioned between the fan and the heat exchanger.

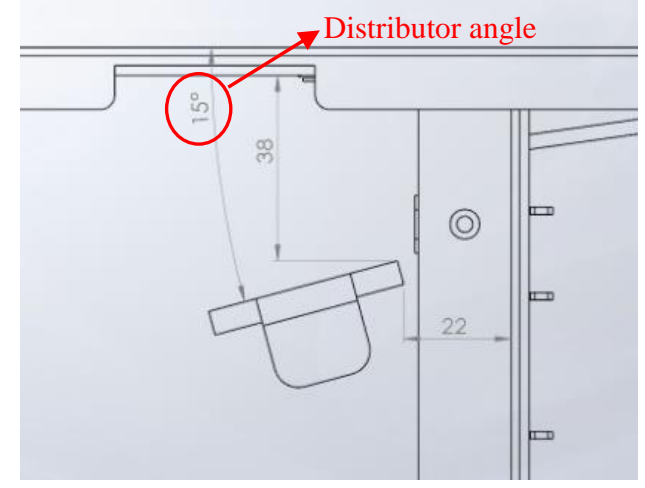

Figure 5. Positioning of distributor

After the analysis performed with the air distributor positioned at a $15^{\circ}$ angle, the resulting air distribution is shown in Figure 6. and Figure 7. In addition, the flow rates from the analysis are given in Table 4.

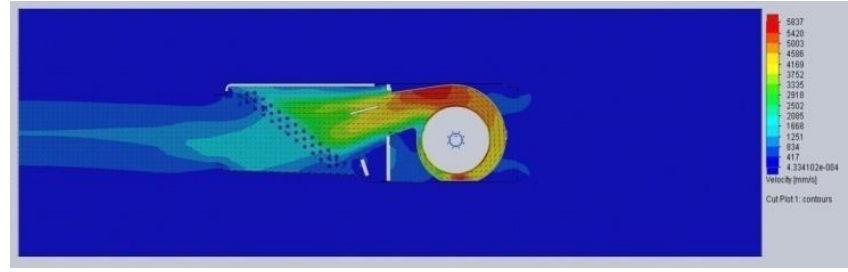

Figure 6. Airflow distribution with $15^{\circ}$ distributor for left fan center plane

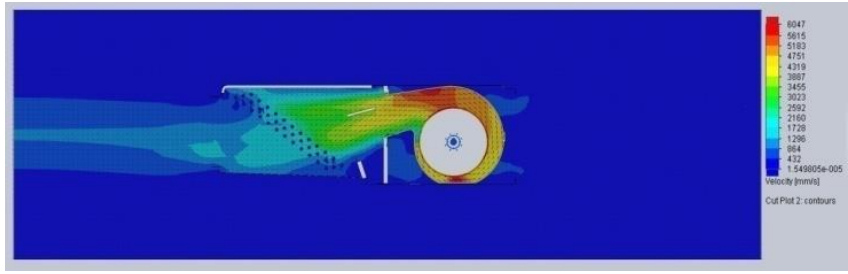

Figure 7. Airflow distribution with $15^{\circ}$ distributor for right fan center plane

Table 4. Maximum air velocities on heat exchanger with $15^{\circ}$ angled distributor

\begin{tabular}{|c|c|c|}
\hline $\begin{array}{c}\text { Copper } \\
\text { Pipe No }\end{array}$ & $\begin{array}{c}\text { Left Fan Air } \\
\text { Velocity (mm/s) }\end{array}$ & $\begin{array}{c}\text { Right Fan Air } \\
\text { Velocity (mm/s) }\end{array}$ \\
\hline 1 & 1119.313 & 805.192 \\
\hline 2 & 602.208 & 521.444 \\
\hline 3 & 940.572 & 893.457 \\
\hline 4 & 2217.612 & 2121.312 \\
\hline 5 & 1997.29 & 1870.041 \\
\hline 6 & 2060.85 & 2028.221 \\
\hline 7 & 2262.714 & 2287.11 \\
\hline 8 & 2330.73 & 2405.143 \\
\hline 9 & 2605.061 & 2698.027 \\
\hline 10 & 784.401 & 895.974 \\
\hline 11 & 1312.201 & 1480.876 \\
\hline 12 & 670.718 & 790.266 \\
\hline
\end{tabular}

\subsection{Determination of Airflow Generated with $30^{\circ}$ Angled Distributor}

The distribution of air generated by the analysis carried out with the air distributed placed at $30^{\circ}$ angle is shown in figure 8 , figure 9 , and the related data are shown in table 5.

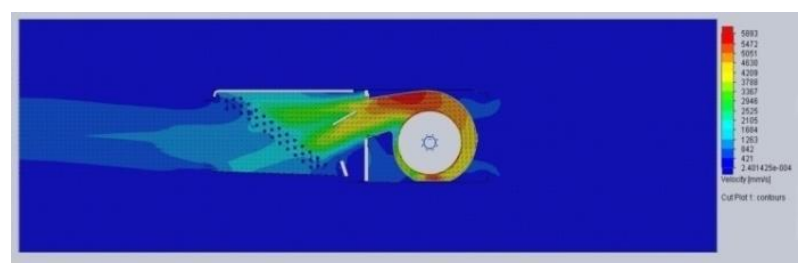

Figure 8. Airflow distribution with $30^{\circ}$ distributor for left fan center plane 


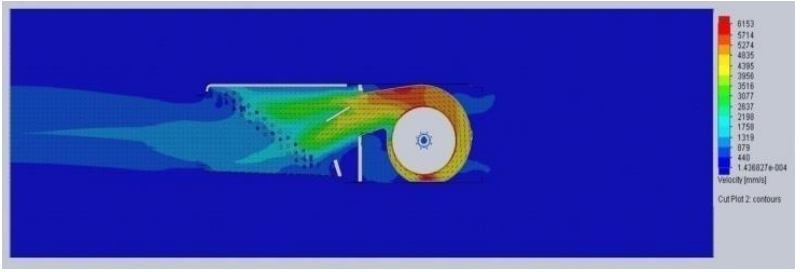

Figure 9. Airflow distribution with $30^{\circ}$ distributor for right fan center plane

Table 5. Maximum air velocities on heat exchanger with $30^{\circ}$ angled distributor

\begin{tabular}{|c|c|c|}
\hline $\begin{array}{c}\text { Copper } \\
\text { Pipe No }\end{array}$ & $\begin{array}{c}\text { Left Fan Air } \\
\text { Velocity (mm/s) }\end{array}$ & $\begin{array}{c}\text { Right Fan Air } \\
\text { Velocity (mm/s) }\end{array}$ \\
\hline 1 & 1097.501 & 812.566 \\
\hline 2 & 595.675 & 587.544 \\
\hline 3 & 1021.164 & 926.747 \\
\hline 4 & 2217.51 & 2172.401 \\
\hline 5 & 1973.297 & 1936.934 \\
\hline 6 & 1971.924 & 1862.86 \\
\hline 7 & 1746.69 & 1588.74 \\
\hline 8 & 1894.531 & 1735.192 \\
\hline 9 & 2654.62 & 2601.39 \\
\hline 10 & 1001.666 & 1060.501 \\
\hline 11 & 1650.643 & 1680.563 \\
\hline 12 & 874.681 & 920.291 \\
\hline
\end{tabular}

\subsection{Determination of Airflow Generated with $45^{\circ}$ Angled Distributor}

The air distributor angle is positioned at $45^{\circ}$ and the results are given in figure 10, figure 11 and table 6 .

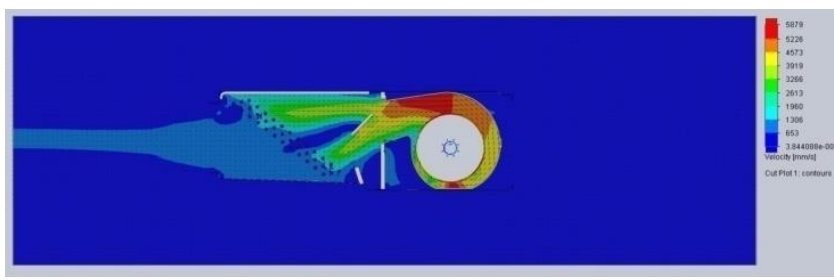

Figure 10. Airflow distribution with $45^{\circ}$ distributor for left fan center plane

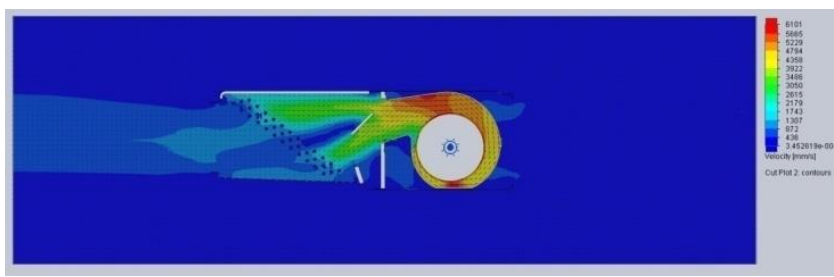

Figure 11. Airflow distribution with $45^{\circ}$ distributor for right fan center plane
Table 6. Maximum air velocities on heat exchanger with $45^{\circ}$ angled distributor

\begin{tabular}{|c|c|c|}
\hline $\begin{array}{c}\text { Copper } \\
\text { Pipe No }\end{array}$ & $\begin{array}{c}\text { Left Fan Air } \\
\text { Velocity }(\mathbf{m m} / \mathbf{s})\end{array}$ & $\begin{array}{c}\text { Right Fan Air } \\
\text { Velocity }(\mathbf{m m} / \mathbf{s})\end{array}$ \\
\hline 1 & 1188.125 & 482.982 \\
\hline 2 & 563.77 & 627.594 \\
\hline 3 & 957.161 & 932.029 \\
\hline 4 & 2279.099 & 2334.19 \\
\hline 5 & 2005.287 & 1866.79 \\
\hline 6 & 1813.844 & 1604.06 \\
\hline 7 & 1244.674 & 964.85 \\
\hline 8 & 688.62 & 647.76 \\
\hline 9 & 1655.825 & 1698.171 \\
\hline 10 & 732.367 & 754.393 \\
\hline 11 & 1830.345 & 1852.444 \\
\hline 12 & 1215.076 & 1277.246 \\
\hline
\end{tabular}

\section{Discussion and Assessment}

The data obtained after the analyzes performed to examine the air flow velocity values formed in the heat exchanger are compared with table 7 . and table 8.

Through the obtained findings with the help of the analysis performed in the initial condition, it is evaluated that the critical points of the flow were formed by copper pipes $1,2,3$ covering upper region and $10,11,12$ covering lower region.

Table 7. Max air velocities for left fan under different conditions $L=60 \mathrm{~mm}$

\begin{tabular}{|c|c|c|c|c|}
\hline $\begin{array}{c}\text { Copper } \\
\text { Pipe } \\
\text { No }\end{array}$ & $\begin{array}{c}\text { Initial } \\
\text { Air } \\
\text { Velocity } \\
(\mathbf{m m} / \mathbf{s})\end{array}$ & $\begin{array}{c}\mathbf{1 5}^{\circ} \text { Air } \\
\text { Velocity } \\
(\mathbf{m m} / \mathbf{s})\end{array}$ & $\begin{array}{c}\mathbf{3 0}^{\circ} \text { Air } \\
\text { Velocity } \\
(\mathbf{m m} / \mathbf{s})\end{array}$ & $\begin{array}{c}\mathbf{4 5}^{\circ} \text { Air } \\
\text { Velocity } \\
(\mathbf{m m} / \mathbf{s})\end{array}$ \\
\hline 1 & 396.934 & 1119.313 & 1097.501 & 1188.125 \\
\hline 2 & 504.89 & 602.208 & 595.675 & 563.77 \\
\hline 3 & 919.998 & 940.572 & 1021.164 & 957.161 \\
\hline 4 & 2513.85 & 2217.612 & 2217.51 & 2279.099 \\
\hline 5 & 2508.369 & 1997.29 & 1973.297 & 2005.287 \\
\hline 6 & 2623.353 & 2060.85 & 1971.924 & 1813.844 \\
\hline 7 & 2642.554 & 2262.714 & 1746.69 & 1244.674 \\
\hline 8 & 2443.594 & 2330.73 & 1894.531 & 688.62 \\
\hline 9 & 2421.774 & 2605.061 & 2654.62 & 1655.825 \\
\hline 10 & 631.439 & 784.401 & 1001.666 & 732.367 \\
\hline 11 & 1022.991 & 1312.201 & 1650.643 & 1830.345 \\
\hline 12 & 493.804 & 670.718 & 874.681 & 1215.076 \\
\hline
\end{tabular}


Table 8. Max air velocities for right fan under different conditions $L=60 \mathrm{~mm}$

\begin{tabular}{|c|c|c|c|c|}
\hline $\begin{array}{c}\text { Copper } \\
\text { Pipe } \\
\text { No }\end{array}$ & $\begin{array}{c}\text { Initial } \\
\text { Air } \\
\text { Velocity } \\
(\mathbf{m m} / \mathbf{s})\end{array}$ & $\begin{array}{c}\mathbf{1 5}^{\circ} \text { Air } \\
\text { Velocity } \\
(\mathbf{m m} / \mathbf{s})\end{array}$ & $\begin{array}{c}\mathbf{3 0}^{\circ} \text { Air } \\
\text { Velocity } \\
(\mathbf{m m} / \mathbf{s})\end{array}$ & $\begin{array}{c}\mathbf{4 5}^{\circ} \text { Air } \\
\text { Velocity } \\
(\mathbf{m m} / \mathbf{s})\end{array}$ \\
\hline 1 & 437.354 & 805.192 & 812.566 & 482.982 \\
\hline 2 & 549.828 & 521.444 & 587.544 & 627.594 \\
\hline 3 & 886.105 & 893.457 & 926.747 & 932.029 \\
\hline 4 & 2474.688 & 2121.312 & 2172.401 & 2334.19 \\
\hline 5 & 2489.996 & 1870.041 & 1936.934 & 1866.79 \\
\hline 6 & 2661.75 & 2028.221 & 1862.86 & 1604.06 \\
\hline 7 & 2703.829 & 2287.11 & 1588.74 & 964.85 \\
\hline 8 & 2265.297 & 2405.143 & 1735.192 & 647.76 \\
\hline 9 & 2212.368 & 2698.027 & 2601.39 & 1698.171 \\
\hline 10 & 716.374 & 895.974 & 1060.501 & 754.393 \\
\hline 11 & 1316.357 & 1480.876 & 1680.563 & 1852.444 \\
\hline 12 & 713.529 & 790.266 & 920.291 & 1277.246 \\
\hline
\end{tabular}

With a $15^{\circ}$ air distributor placement, the flow rate increases up to $183 \%$ in the upper and lower regions of the heat exchanger. However, in particular the increase in the lower zone is not equivalent to the values obtained with the $30^{\circ}$ air distributor. On the other hand, copper pipes 5, 6, 7 and 8 located in the central region of the heat exchanger; the lowest reduction compared to the initial conditions is determined at this location. With a $30^{\circ}$ air distributor layout, up to $177 \%$ flow rate increase is achieved in areas designated as design improvement criteria. As noted in the previous evaluation, the velocity increase in the lower regions is higher than the $15^{\circ}$ placement. The increase amounts in this targeted sub-region constituted the most significant design output with rates of $59 \%, 61 \%$ and $77 \%$, respectively.

The $45^{\circ}$ air distributor placement is at the foreground due to the blocking effect between the blower mouth and the heat exchanger. The extreme rate drops of up to $86 \%$ in the central region causes a high fluctuation in the air distribution over the heat exchanger. On the other hand, the highest velocity values in the lower region of the heat exchanger are observed at this location.

When examining the advantages and disadvantages of three different placement angles in order to achieve optimum values of the air distribution on the heat exchanger targeted at the beginning of the work, it is observed that the optimum design angle is $30^{\circ}$ air distributor placement.

In addition to the findings obtained, improvements can be anticipated in the design of the air distributor in order to reduce the direct obstruction of air contact

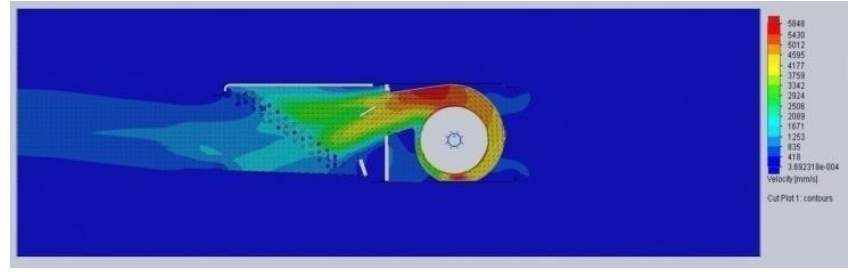

Figure 12. Airflow distribution with $L=40 \mathrm{~mm} 30^{\circ}$ distributor for left fan center plane

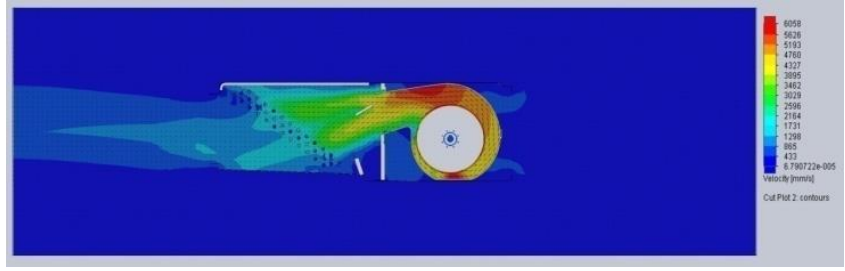

Figure 13. Airflow distribution with $L=40 \mathrm{~mm} 30^{\circ}$ distributor for left fan center plane

Table 9. Max air velocities for left fan based on air distributor lengths

\begin{tabular}{|c|c|c|c|}
\hline $\begin{array}{c}\text { Copper } \\
\text { Pipe } \\
\text { No }\end{array}$ & $\begin{array}{c}\text { Initial Air } \\
\text { Velocity } \\
(\mathbf{m m} / \mathbf{s})\end{array}$ & $\begin{array}{c}\text { L=60 mm Air } \\
\text { Velocity } \\
(\mathbf{m m} / \mathbf{s})\end{array}$ & $\begin{array}{c}\text { L=40 mm Air } \\
\text { Velocity } \\
(\mathbf{m m} / \mathbf{s})\end{array}$ \\
\hline 1 & 396.934 & 1097.501 & 1049.231 \\
\hline 2 & 504.89 & 595.675 & 962.682 \\
\hline 3 & 919.998 & 1021.164 & 1132.134 \\
\hline 4 & 2513.85 & 2217.51 & 2208.586 \\
\hline 5 & 2508.369 & 1973.297 & 2107.038 \\
\hline 6 & 2623.353 & 1971.924 & 2075.489 \\
\hline 7 & 2642.554 & 1746.69 & 1959.941 \\
\hline 8 & 2443.594 & 1894.531 & 2035.393 \\
\hline 9 & 2421.774 & 2654.62 & 2714.845 \\
\hline 10 & 631.439 & 1001.666 & 1110.296 \\
\hline 11 & 1022.991 & 1650.643 & 1704.748 \\
\hline 12 & 493.804 & 874.681 & 946.201 \\
\hline
\end{tabular}

of the tubes in the central region. In this direction, with the design update of air distributor length from $60 \mathrm{~mm}$ to $40 \mathrm{~mm}$, the final flow distribution is shown in Figure 12 and Figure 13, and the flow data is given in Table 9. and Table 10.

\section{Conclusion}

When the air flow data evaluated in the completed analysis studies are investigated, the conclusion created by the air distributor design can be summarized as follows: The air flow in the upper part of the heat exchanger copper tubes 1, 2 and 3 is increased by $1322,225 \mathrm{~mm} / \mathrm{s}$ for the left fan and by $977,218 \mathrm{~mm} / \mathrm{s}$ for the right fan, thus improving the air distribution in this region by $73 \%$ and $52 \%$. 
Table 100. Max air velocities for right fan based on air distributor lengths

\begin{tabular}{|c|c|c|c|}
\hline $\begin{array}{c}\text { Copper } \\
\text { Pipe } \\
\text { No }\end{array}$ & $\begin{array}{c}\text { Initial Air } \\
\text { Velocity } \\
(\mathbf{m m} / \mathbf{s})\end{array}$ & $\begin{array}{c}\text { L=60 mm Air } \\
\text { Velocity } \\
(\mathbf{m m} / \mathbf{s})\end{array}$ & $\begin{array}{c}\text { L=40 mm Air } \\
\text { Velocity } \\
(\mathbf{m m} / \mathbf{s})\end{array}$ \\
\hline 1 & 437.354 & 812.566 & 1010.764 \\
\hline 2 & 549.828 & 587.544 & 830.835 \\
\hline 3 & 886.105 & 926.747 & 1008.906 \\
\hline 4 & 2474.688 & 2172.401 & 2278.987 \\
\hline 5 & 2489.996 & 1936.934 & 2080.049 \\
\hline 6 & 2661.75 & 1862.86 & 2094.12 \\
\hline 7 & 2703.829 & 1588.74 & 1906.191 \\
\hline 8 & 2265.297 & 1735.192 & 1989.737 \\
\hline 9 & 2212.368 & 2601.39 & 2198.661 \\
\hline 10 & 716.374 & 1060.501 & 1358.595 \\
\hline 11 & 1316.357 & 1680.563 & 1761.624 \\
\hline 12 & 713.529 & 920.291 & 965.453 \\
\hline
\end{tabular}

In the central region consisting of copper tubes of heat exchangers $4,5,6,7,8$ and 9 , the total air distribution is approximately $15 \%$ with a total reduction of $2052,252 \mathrm{~mm} / \mathrm{s}$ for the left fan and 2260 $\mathrm{mm} / \mathrm{s}$ for the right fan. Nevertheless, it is possible to balance the reductions in this region with a total increase of $2899,236 \mathrm{~mm} / \mathrm{s}$ and $2376,629 \mathrm{~mm} / \mathrm{s}$ obtained in regions 1 and 3 .

In the lower region of the heat exchanger consisting of copper tubes 10,11 and 12, an increase in air flow of $1577,011 \mathrm{~mm} / \mathrm{s}$ for the left fan and $1399,411 \mathrm{~mm} / \mathrm{s}$ for the right fan was observed and improvement of the air distribution in this region by $75 \%$ and $49 \%$.

Considering the investigations and the findings obtained, it has been found that, as a result of the air distributor design to be realized, a more uniform structure of the air distribution over the heat exchanger makes it possible to achieve a more homogeneous flow.

\section{Acknowledgement}

Authors thanks to DAIKIN Turkey R\&D Department for their contributions to this study.

\section{References}

[1] N. Kim, D. Kim, Y. Choi, H. Byun, J. Hwang, "Effect of Inclination Angle on the Air-side Performance of Aluminum Parallel Flow Heat Exchangers Under Wet Conditions", International Refrigeration and Air Conditioning Conference, 2008.

[2] P. Karthik, V. Kumaresan, R. Velraj, "Experimental and Parametric Studies of A Louvred Fin and Flat
Tube Compact Heat Exchanger Using Computational Fluid Dynamics", Alexandria Engineering Journal, vol. 54, no. 4, pp. 905-915, 2015. https://doi.org/10.1016/j.aej.2015.08.003

[3] A. Vaisi, M. Esmaeilpour, H. Taherian, "Experimental Investigation of Geometry Effects on the Performance of A Compact Louvred Heat Exchanger", Applied Thermal Engineering, vol. 31, no. 16, pp. 3337-3346, 2011.https://doi.org/10.1016/j.applthermaleng.2011.0 $\underline{6.014}$

[4] W. J. Lee, J. H. Jeong, "Heat Transfer Performance Variations of Condensers Due to Non-Uniform Air Velocity Distributions", International Journal of Refrigeration, vol. 69, p. 85-95, 2016.https://doi.org/10.1016/j.ijrefrig.2016.05.009

[5] A. Firouzar, "Bir Fan-Coil Ünitesinin Performansının Deneysel ve Sayısal Olarak Analizi", Gazi University, Science Institue, Mechanical Engineering Department, MSc Thesis, 2014.

[6] Eurovent RS 6/C/002-2017, "Rating Standard for The Certification of Non-Ducted Fan-coil Ünits", Paris: Eurovent Certita Certification, p. 4-7. 